\title{
Comunicação
}

[Communication]

\section{Prevalência da infecção por lentivírus de pequenos ruminantes em caprinos em Teresina, Piauí}

[Prevalence of small ruminants lentiviruses infection in goats from Teresina, Piauí, Brazil]

\author{
A. Sampaio Júnior ${ }^{1}$, M.C.S. Batista ${ }^{1}$, M.S.P. Cruz ${ }^{1}$, R.A.B. Silva ${ }^{1}$, \\ C. Bona Nascimento ${ }^{1}$, G.L. Werneck ${ }^{2 *}$ \\ ${ }^{1}$ Programa de Pós-Graduação em Ciência Animal, Universidade Federal do Piauí \\ ${ }^{2}$ Departamento de Endemias Samuel Pessoa - Escola Nacional de Saúde Pública - Fundação Oswaldo Cruz \\ Rua Leopoldo Bulhões, 1480 \\ 21041-210 - Manguinhos - Rio de Janeiro, RJ
}

A criação de caprinos caracteriza-se, na maioria das vezes, pelo baixo uso de tecnologia, facilitando a prevalência de enfermidades infecciosas, parasitárias e carenciais, principais entraves à sua expansão. Dentre as enfermidades infecciosas, destacam-se as lentiviroses de pequenos ruminantes (LVPR), denominação genérica que recebem as doenças produzidas pelos vírus da artrite-encefalite caprina (CAEV) e Maedi-Visna (MVV) e que acometem caprinos e ovinos em diversas partes do mundo (Reina et al., 2008).

Os lentivírus (LV) são RNA-vírus pertencentes à família Retroviridae, subfamília Lentivirinae. Os primeiros relatos consideravam que esses vírus eram espécie-específicos, porém estudos têm demonstrado sua capacidade de cruzar barreiras interespécies e de adaptar-se a novos hospedeiros (Morin et al., 2002). Os LV causam doenças degenerativas progressivas lentas e determinam importantes perdas econômicas, dentre elas a redução na produção de leite, diminuição da vida produtiva, retardo no crescimento, desvalorização nos plantéis com sorologia positiva, além de gastos financeiros em programas de controle e erradicação (Callado et al., 2001; Reina et al., 2008).

O reservatório e a fonte de infecção das LVPR são os caprinos e ovinos infectados. Assim, a detecção dos animais portadores é essencial para o controle da doença. O isolamento do agente demanda tempo e requer infraestrutura laboratorial sofisticada. Desse modo, o diagnóstico sorológico, especialmente pela técnica da imunodifusão em gel de agarose (IDGA), representa uma alternativa viável, por ser de fácil execução e não necessitar de grande infraestrutura laboratorial (Castro, 1998).

No Brasil, após as primeiras descrições de animais soropositivos no Rio Grande do Sul e no Rio de Janeiro (Callado et al., 2001), surgiram relatos de soropositividade em caprinos de vários outros estados, tais como: Pernambuco (Castro et al., 2002), Paraíba (Castro et al., 2002), Ceará (Melo e Franke, 1997) e Piauí (Batista et al., 2004).

Considerando-se a importância de se obter dados mais consistentes sobre a ocorrência dessas enfermidades, este trabalho teve como objetivo estimar a prevalência da infecção por LV em rebanhos caprinos do município de Teresina, Piauí.

Um estudo soroepidemiológico com delineamento seccional foi utilizado para estimar a prevalência da infecção por lentivírus em caprinos aparentemente saudáveis, pertencentes a propriedades rurais cadastradas na Associação Piauiense de Criadores de Caprinos e Ovinos (APICCOVI). Para seleção dos animais,

Recebido em 4 de janeiro de 2011

Aceito em 21 de março de 2011

*Autor para correspondência (corresponding author)

E-mail: gwerneck@ensp.fiocruz.br 
realizou-se prévio contato com APICCOVI visando à obtenção de dados sobre criatórios caprinícolas localizados no município de Teresina. Os cadastros revelaram um plantel de 2.066 caprinos distribuídos em nove propriedades rurais. Dentre estas, três apresentavam efetivo menor que 50 animais e não foram incluídas neste estudo. As seis propriedades restantes eram responsáveis por um total de 1979 caprinos (95,8\% do total).

Em cada uma das seis propriedades selecionadas para participar do estudo, foi selecionado aleatoriamente um número predeterminado de animais, variando de $6,7 \%$ a $41,7 \%$ do total de cabeças. O tamanho amostral calculado foi de aproximadamente 473 animais, considerando-se expectativa de positividade à sorologia de 2,5\%, erro alfa de $5 \%$, erro absoluto para cada lado de 1,25\%. Foram obtidas amostras válidas para 480 animais.

As amostras de sangue foram colhidas por punção da veia jugular externa, utilizando-se o sistema de colheita a vácuo, em frascos vacutainer com capacidade para $10 \mathrm{~mL}$, sem anticoagulante. As amostras de sangue, já coaguladas, foram centrifugadas a 2000rpm, por 10 minutos, para obtenção do soro, o qual foi dividido em alíquotas de $1,5 \mathrm{~mL}$ em microtubos tipo eppendorf e congeladas a $-20^{\circ} \mathrm{C}$, até $\mathrm{o}$ momento de realização das análises. Os exames foram realizados utilizando-se o kit para diagnóstico de Maedi-Visna (IDGA; Biovetech Indústria e Comércio de Produtos Biotecnológicos Ltda. - ME Recife, Brasil) composto de antígeno, soro padrão positivo e solução de agarose a $1 \%$ em tampão borato (Lombardi et al., 2009).
Para a realização dos testes, aqueceu-se a solução de agarose em banho-maria até sua total dissolução e, em seguida, utilizando-se uma pipeta pré-aquecida, distribuíram-se $14 \mathrm{~mL}$ em placas de Petri de $90 \mathrm{~mm}$ de diâmetro. Após a solidificação do gel, as placas foram estocadas em refrigerador por 24 horas, quando foi feita, então, a perfuração do gel, usando-se rosetas de sete orifícios, de $4 \mathrm{~mm}$ de diâmetro e $3 \mathrm{~mm}$ de distância entre as bordas, sendo uma central, onde foi depositado o antígeno $(20 \mu \mathrm{L})$, e seis periféricas equidistantes, nas quais foram colocados $20 \mu \mathrm{L}$ de soro teste e igual volume do soro padrão positivo, alternadamente. As placas foram mantidas em atmosfera úmida à temperatura de $25^{\circ} \mathrm{C}$, por 48 horas, quando foi feita a leitura definitiva (Batista et al., 2004).

Para a análise estatística, utilizou-se o software Stata 9.0. Calcularam-se a prevalência total e a prevalência segundo o sexo e a faixa etária considerando-se as frações amostrais correspondentes a cada fazenda.

A Tab. 1 apresenta o tamanho total do rebanho, o tamanho da amostra selecionada e a prevalência de infecção por lentivírus de pequenos ruminantes em caprinos do município de Teresina por fazenda incluída no estudo. A prevalência variou de $1,8 \%$ a $20,0 \%$ entre as fazendas, sendo a prevalência global de infecção por LVPR estimada em 4,2\%, após correção para variações das frações de amostragem entre as fazendas. A prevalência estimada neste estudo é cerca de duas vezes mais elevada do que a encontrada por Batista et al. (2004). Esses autores utilizaram animais oriundos de rebanhos de nove municípios no estado do Piauí.

Tabela 1. Tamanho total do rebanho, tamanho da amostra selecionada e prevalência de infecção por lentivírus de pequenos ruminantes em caprinos do município de Teresina por fazenda

\begin{tabular}{cccc}
\hline Propriedade & $\begin{array}{c}\text { Animais por } \\
\text { rebanho }(\mathrm{N})\end{array}$ & $\begin{array}{c}\text { Amostra } \\
(\mathrm{N})\end{array}$ & $\begin{array}{c}\text { Prevalência } \\
(\%)\end{array}$ \\
\hline 1 & 300 & 102 & $4(3,9)$ \\
2 & 120 & 50 & $1(2,0)$ \\
3 & 150 & 10 & $2(20,0)$ \\
4 & 300 & 40 & $2(5,0)$ \\
5 & 180 & 53 & $2(3,8)$ \\
6 & 929 & 225 & $4(1,8)$ \\
Total & 1979 & 480 & $15(3,1)^{*}$ \\
\hline
\end{tabular}

* Prevalência não ajustada para variações das frações de amostragem entre as fazendas. 
A prevalência de positividade foi estimada em $4,2 \%$ nas fêmeas e 3,6\% nos machos. Mesmo considerando-se o pequeno número de machos que compõe os rebanhos em Teresina, a prevalência encontrada em machos merece particular atenção, pois eles podem servir como fonte de infecção para todo o rebanho. Pinheiro et al. (2001) também sugeriram que os machos possam constituir fonte de infecção para todo o rebanho.

A prevalência aumentou com a idade: 2,3\% em animais com menos de um ano de idade, 2,9\% entre um e três anos, $6,1 \%$ entre três e cinco anos e $8,2 \%$ entre cinco e sete anos. Estes resultados assemelham-se aos de Pinheiro et al. (2001) e Bandeira (2005), que avaliaram rebanhos nos estados do Ceará e Paraíba, respectivamente, e verificaram que a prevalência de animais reagentes aumenta com a faixa etária. Dawson e Wilesmith (1985) relataram maior soropositividade em caprinos com mais de cinco anos de idade. De acordo com McGuire (1987), há maior positividade em animais mais velhos decorrente do caráter insidioso da doença e do tempo de permanência em contato com outros, o que resulta em maior probabilidade de exposição dos animais ao vírus.

Entre os positivos, 29,4\% eram animais puros, sendo 23,5\% da raça Anglo Nubiana e 5,9\% da raça Boer, 35,3\% mestiços - oriundos do cruzamento de Anglo Nubiana com Boer - e 35,3\% animais sem raça definida (SRD). Batista et al. (2004) encontraram maior percentual de positivos na raça Anglo Nubiana, seguida da Boer e da SRD, em estudo realizado no estado do Piauí. Isso, provavelmente, deve-se à predominância dessas raças nos rebanhos caprinos do estado.

Os resultados do presente estudo sugerem que a positividade dos casos desta infecção vem sendo mantida em níveis endêmicos ao longo dos anos.

Palavras-chave: vírus da artrite-encefalite caprina, transmissão, epidemiologia, imunodifusão

\begin{abstract}
The prevalence of anti-lentiviruses antibodies of small ruminants was investigated in goat herds in the city of Teresina, PI, Brazil. A seroepidemiological survey was conducted involving 480 animals, apparently healthy, belonging to six rural properties. The diagnostic test was the agar gel immunodiffusion (AGID), using antigens produced from cellular cultures infected with caprine arthritis encephalitis virus (CAEV Cork). Prevalences by gender and age were estimated considering sampling fractions for each farm. A general prevalence of 4.2\%, was observerved, being $4.2 \%$ for females and 3.6\% for males. Prevalences were higher among older goats. Regarding the breed standard, 23.5\% were of the Anglo Nubian, 5.9\% of the Boer, 35.3\% Anglo Nubian x Boer crossbred, and 35.3\% of undefined breed. It is concluded that small ruminant lentiviruses are endemic among goat herds of Teresina.
\end{abstract}

Keywords: caprine arthritis encephalitis virus, transmission, epidemiology, immunodiffusion

\section{AGRADECIMENTOS}

Gustavo de Souza Lima, Antônio Vítor Mourão Santana Rufino e Roberto Soares de Castro, pelas sugestões; ao CNPq, pelo apoio financeiro (Proc. 483657/2006-9 e 308889/2007-0); à FAPEPI/CNPq, pelo apoio financeiro (Edital PPP 01/2006), à CAPES, pela bolsa de mestrado ao primeiro autor.

\section{REFERÊNCIAS BIBLIOGRÁFICAS}

BANDEIRA, D.A. Características sanitárias de produção da caprinocultura nas microrregiões do Cariri do estado da Paraíba. 2005. 114f. Tese (Doutorado em Ciência Veterinária) - Universidade Federal Rural de Pernambuco, Recife, PE.

BATISTA, M.C.S.; CASTRO, R.S.; CARVALHO, F.A.A. et al. Anticorpos anti-lentivírus de pequenos ruminantes em caprinos do estado do Piauí. Cienc. Vet. Trop., v.76, p.75-81, 2004. 
CALLADO, A.K.C.; CASTRO, R.S.; TEIXEIRA, M.F.S. Lentivirus de pequenos ruminantes (CAEV e Maedi-Visna): revisão e perspectivas. Pesqui. Vet. Bras., v.21, p.87-97, 2001.

CASTRO, R.S. Lentivírus de pequenos ruminantes: ensaios imunoenzimáticos, perfil sorológico e inferências filogenéticas. 1998. 132f. Tese (Doutorado em Ciência Veterinária) - Escola de Veterinária, Universidade Federal de Minas Gerais, Belo Horizonte, MG.

CASTRO, R.S.; AZEVEDO, E.O.; TABOSA, I. et al. Anticorpos para o vírus da artrite-encefalite caprina em animais sem raça definida (SRD) de abatedouros dos estados de Pernambuco e Paraíba. Cienc. Vet. Trop., v.5, p.121-123, 2002.

DAWSON, M.; WILESMITH, J.M. Serological survey of lentivirus (maedi-visna/ caprine arthritis encephalitis) infection in British goat herds. Vet. Rec., v.117, p.86-89, 1985.

LOMBARDI, A.L.; NOGUEIRA, A.H.C.; FERES, F.C. et al. Soroprevalência de Maedi-Visna em ovinos na região de Araçatuba, SP. Arq. Bras. Med. Vet. Zootec., v.61, p.1434-1437, 2009.
McGUIRE, T.C. The immune response to viral antigens as a determinant of arthritis in caprine arthritis-encephalitis infection. Vet. Immunol. Immunop., v.17, p.465-470, 1987.

MELO, A.C.M.; FRANKE, C.R. Soroprevalência da infecção pelo vírus da artrite-encefalite caprina (CAEV) no rebanho de caprinos leiteiros da região da grande Fortaleza, Ceará, Brasil. Cienc. Rural, v.27, p.113-117, 1997.

MORIN, T.; MSELLI-LAKHAL, L.; BOUZAR, B. et al. Caprine arthritis encephalitis virus (CAEV) and the species barrier. Virologie, v.6, p.279-291, 2002.

PINHEIRO, R.R.; GOUVEIA, A.M.G.; ALVES, F.F. Prevalência da infecção pelo vírus da artrite encefalite caprina no estado do Ceará, Brasil. Cienc. Rural, v.31, p.449-454, 2001.

REINA, R.; BERRIATUA, E.; LUJÁN, L. et al. Prevention strategies against small ruminant lentiviruses: an update. Vet. J., v.182, p. 31-37, 2008. 